\section{PP2-001 腎細胞癌に性差間の特徵はあるか}

\section{日本大学泌尿器科}

川田 望, 矢ヶ崎 宏紀, 森田 恒太郎, 長根裕介, 仲野谷 佑嗣, 五十嵐 匠, 平方 仁, 滝本 至得

【目的】腎細胞癌で性差における臨床病理学的相違がある か検討する。【対象、方法】原発巣を摘除した腎細胞癌症 例 162 例、男性 126 例（中央値 59 歳、範囲 31-81 歳） 女性 36 例 (60 歳、17-80 歳)。Grade は 1、2、3、が各々 87 例、61 例、14 例であった。検討項目は、腫瘍最大径、へ モグロビン (Hb), ALP, IAP, Ferritin そして免疫組織学 的に血管新生因子である dThdPase と Factor VIII related antigen（VIII）である。結果】男性 126 例 中 85 例 $(67 \%)$ が偶発癌で、逆に女性 36 例中 25 例 $(69 \%)$ が 症候癌であった $(\mathrm{p}<0.001)$ 。 162 例の 5 年生存率は男性、 女性が各々 $77.7 \%, 73.4 \%(\mathrm{NS}) 。$ 遠隔転移のない 143 例の 5 年非再発率は男性、女性が各々 $82.4 \%, 76.4 \%$ で あった (NS)。最大腫舓径、CRP、Hb で有意に差が認め られ、各々 $\mathrm{m}<\mathrm{f}, \mathrm{m}<\mathrm{f}, \mathrm{m}>\mathrm{f}$ であった $(\mathrm{p}<0.05)$ 。一方細 胞型、異型度、dThdPase、そしてVIII では男女間に明ら かな差は認められなかった。考察】女性は症候癌が多く、 遠隔成績と関係する CRP、腫場最大径では女性が男性を 凌いでいたが、遠隔成績では男女間に差は認められな かった。

\section{PP2-002 若年性腎癌の臨床的検討}

京都府立医科大学泌尿器科学教室 ${ }^{1}$, 明治銊炎大学泌尿 器科 $2^{2}$, 京都第二赤十字病院泌尿器科 ${ }^{3}$, 社会保険京都 病院泌尿器科 4

白石 匠", 水谷 陽一", 三神 一哉11, 野本 剛史", 中村 晃和 ${ }^{1}$, 中西 弘之 ${ }^{11}$, 中内 博夫 ${ }^{11}$, 三木 恒治 ${ }^{11}$, 中尾昌宏 ${ }^{2}$, 井上 亘 ${ }^{3 i}$, 大江 宏 ${ }^{3}$, 木村 泰典 ${ }^{4)}$, 鴨井 和美 ${ }^{4}$ 【目的】 40 歳未満のいわゆる若年性腎癌は、40 歳以上の腎癌と比 べ女性の比率が高い、予後が良好であるなどの特徵を有するとい われているが、不明な点も多い。京都府立医科大学・京都第二赤

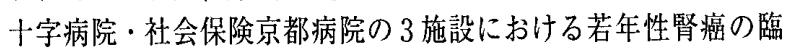
床的檢討を行った。刘象】 1976 年から 2002 年の 27 年間に䛦断さ れた腎癌は 461 例であった。40歳未満の症例を若年性腎癌と定義 し、臨床的検討を行い 40 瓷以上群と比較した。臨床病期・病理等 は、腎癌取り扱い規約第 3 版 (1999) に従った。結果】若年性腎 癌は 18 例 $(4 \%)$ で、診断時年齢は最低が 22 歳、平均 34 藏であっ た。男女比峘男性 13 例 $(72 \%$ ) 、女性 5 例で、40 歳以上の群 (男 性 $68 \%$ ）と同様に男性が多数を占めた。発見契機では、若年性腎 癌で偶然発見癌が $59 \%$ (10 例)、40 歳以上群では $50 \%$ で、ほほ同 様であった。臨床病期では、T1:16例、T2:1例、T3a:1例と、 T1 が 89\%（40 歳以上群では $58 \%$ ) 占めた。Grade は若年性腎 癌と 40 歳以上群との間で分布に大きな違いは認められなかっ た。予後の检討では、若年性腎癌は平均観察期間 80 力月で全例生 存していたのに対して、40歳以上群では 5 年生存率 $71 \% 、 \mathrm{~T} 1$ に症例を限定しても $90 \%$ と、若年性腎癌の予後は良好であった。

\section{PP2-003 腎癌細胞、樹状細胞の融合細胞による 抗腫瘍効果}

\section{岩手医大学細菌学 ${ }^{11}$, 岩手医科大学泌尿器科学 ${ }^{2)}$}

大内 淳 ${ }^{11}$, 堤 玲子 ${ }^{17}$, 近田 龍一郎 ${ }^{2}$, 藤周 知昭 ${ }^{2}$,

佐藤 成大 ${ }^{\prime}$

【目的】樹状綀胞 (DC) 法強力な抗原提示細胞として知られており、 癌治㙩に打いては癌特異的細胞慯害性 T細胞の誘導を目的に応 用されている。今回In vivo でマウス腎癌 (Renca) に対する DC の抗腫瘍効果を検討し、また抗腫瘍効果の増強を目的に Renca と DCの融合細胞 $(\mathrm{FC})$ を作製、その抗腫湟効果を検討した。!方 法】 DC は3 6 週龄の BALB/c マウス骨骮細胞に GM-CSF、IL -4を加え 9 日間培養し作成した。Renca と DCの虽合は、Renca に30Gy の放射線照射後、CUY21 EDIT (BEX CO, LTD) による Electrofusion 法で行い、さらに FACSCalibur (BECTON DICKINSON)でFCを捕集した。FCの形態はGiemsa染色て観察した。 抗腫瘍効果は、Renca 皮下移植モデルに対し移植後 5 日目、12 日目、19日目に DC または FCを投与、腫掦增殖曲線を作製し判定 した。In vitro の抗腫瘍効果は脾䐵リンパ球の、 ${ }^{51} \mathrm{Cr}$ releasing assay、Elispot assay、Apoptosis assay で判定した。結果および考 察]皮下移植モデルでは FC 投与群が DC 投与群、対照群に比べ有 意な抗腫場効果を示した。 FC 投与マウス脾細胞中の IFN- $\gamma$ 産生 細胞は DC 投与群、対照群に比べ有意な增加を示した。In vitro でも $\mathrm{FC}$ 投与群は DC 投与群、対照群に比較し有意に抗腫瘍活性 を示した。これらの結果より FCはDCより多くのRenca特異的 CTLを誘導し、抗腫瘍活性を発揮すると考えられた。

\section{PP2-004 腎細胞癌における CD83 陽性緗胞, CD 8 陽性細胞, CD4 陽性細胞の免疫学的 検討}

\section{昭和大学泌尿器科学教室 ${ }^{1)}$, 昭和大学病院病理科 ${ }^{2)}$ 麻生 太行 ${ }^{1}$, 首藤 直樹 ${ }^{1}$, 黑澤 和宏 ${ }^{1}$, 石川 公建 ${ }^{1}$, 直江 道夫", 深貝 隆志 ${ }^{17}$, 小川 良雄"), 九島 已樹", 吉田 英機)}

(目的)我々は, 腎細泡癌を取り卷く免疫環境を明らかにする目 的で, 腎細胞癌扔よび周囲正常組織を含むパラフイン包埋標本 につき成熟樹状細胞 (mature dendritic cell : $\mathrm{mDC}: \mathrm{CD} 83$ 陽性 練胞), 細胞傷害性 T 細胞 (cytotoxic-T Cell: CD8 陽性細胞), ヘルパーT細胞 (helper-T Cell:CD4 陽性細胞)の分布を免疫 染色で調べ, 各練胞間における出現数に相関が認められるかに ついて検討を行った. (対象と方法) 33 症例の腎細胞癌パラ フィン包埋標本を, 抗 CD4, CD8, CD83 抗体で免疫染色し, 腫 瘍組織, 境界領域, 正常腎組織は 3 つの領域を含む標本につい て，各領域に扩ける CD4, CD8, CD83 陽性細胞数を計測した. (結果) $\mathrm{CD} 4, \mathrm{CD} 8, \mathrm{CD} 83$ 陽性練胞はいずれも境界領域に有意に 多く存在した。また, CD4 陽性細胞と CD83 陽性細胞間 $(r=$ $0.805, \mathrm{p}<0.0001), \mathrm{CD} 8$ 陽性細胞と CD83 陽性細胞間 $(r=0.505$, $\mathrm{p}<0.0001$ ) に有意の相関を認めた（結論) 成熟樹状細胞は抗原 提示紐胞として働き,細胞傷害性 T練胞,ヘルパー T細胞を誘 導することが知られている。腎細胞癌周囲組織に比し腎細胞癌 局所にそれらの細胞が少なかったことは, 腎細胞癌が, 宿主の 免疫監視より逃れている可能性を示唆すると考えられた。 